\title{
Election Campaign for Local Government in the Perspective of Local Government Press
}

\author{
Grazyna Piechota \\ Andrzej Frycz Modrzewski Krakow University, Krakow, Poland
}

\begin{abstract}
Local government press is one of important channels of conveying information in the local space. Its functions are being constantly redefined as a result of the changing paradigm of communicating on the local level. Local government press gains particular importance during any election campaign becoming the carrier of information for local authorities seeking reelection. The following text presents the results of research carried out in selected cities with poviat rights in the last quarter of 2014, during the local government election campaign in Poland.
\end{abstract}

Keywords: local media, local government press, Facebook, local authority, election campaign

\section{Introduction}

Local government media that are issued by many local governments in Poland are at the same time one of the important entities in the group of media published in the local space ${ }^{1}$. They take the form of local government press (the most often) and also internet portals, radio, and even television. Besides local government media in the local space, there are also local commercial media and media (mostly in the form of magazines or internet portals) issued by non-governmental organizations, self-regulatory organizations or religious organizations. Local government media in Poland include monthly magazines which are generally issued directly by local administration (it is usually the department responsible for social communication or promotion in the town hall) or weekly magazines issued usually by municipal companies created for this purpose (Szostok \& Rajczyk, 2013). The legal status of information activities undertaken in the realm of publishing their own media by local governments is unregulated. This means that it is neither directly allowed or prohibited to issue such media. There are also no ethical standards guiding the publication of media by local authorities. The regulations concerning the communes' tasks do not directly mention the right to carry out information policy in the form of own media. Besides, such practices meet with critical opinions of different groups, like media publishers or non-governmental organizations carrying out "watch dog" tasks. Despite numerous doubts, local authorities more often and more eagerly reach for these instruments of communication with local community.

Grazyna Piechota, Lawyer, Ph.D. in Sociology, Assistant Professor, Faculty of Management and Social Communication, Andrzej Frycz Modrzewski Krakow University.

1 Local press is defined in different ways, emphasizing various elements differentiating it from other types of media. According to Kowalczyk (2003), local press should entail press issued in districts of big cities, parishes, housing estates, small towns, communes and poviats. Chorązki and Dziki (2004), on the other hand, define local press emphasizing its limited and predefined spatial reach, local media are strictly connected with the current administrative division of the country. However, according to Sobczak (2005), the local press is singled out on the basis of territorial conditions but is not necessarily connected with the administrative division. 
The basic problem connected with issuing local government media is the fact that the public opinion receives information directly from the decision-makers, getting only a one-sided point of view. In this type of informing the main function of the media, i.e., the control function is not exercised. Another important issue is the fact that such magazines are accessible free of charge, what on the one hand guarantees the members of the local community free access to information but also adversely influences the local press market, where titles issued by commercial entities must be paid for. It is particularly noticeable when magazines are issued by municipal companies that publish official announcements and advertisements, mainly of municipal utility providers. The advertising market in the local space is quite limited and the additional participation of local government media substantially limits the possibility of functioning for local commercial media by limiting their financing from advertisements.

The role of local government media is mainly informative, as research carried out for many years in this field in Poland has revealed. In addition, local government media also have an integrating and activating function in the local community as the carrier of entertainment and promotional content. They should also create a platform for public debate. At present, the functions of local government media are being redefined. This concerns in particular two of the mentioned functions-promotional and creating public debate. This results from the fact that the content is systematically transferred and shared on the internet. In the case of a local government medium available online, the promotional function increases its influence - the content is not only available locally but has a potentially global reach. Also in the local perspective the possibilities of creating public discourse change, the public forum is transferred to the internet (using social media) and thus creates the possibility of engaging users into the discussion, regardless of the place they are in. It is also not necessary for all the interlocutors to participate in the discussion at the same time-discourse within the same thread may take even a few days. However, local government media do not play a controlling role. If they did, it would actually have to be self-control of the entity that is at the same time the publisher.

This publication will present the main results of research carried out in the period from September to November, 2014 during an election campaign for local governments (research has been limited to the analysis of using local government press in elections for the offices of mayor) ${ }^{2}$. The content of selected local government magazines has been analyzed (seventy three issues from the period September-November 2014), provided by cities with poviat rights, also in the electronic version. For research purposes the course of public discourse on the internet concerning content published by the studied papers has been followed, if the editors allowed for such a possibility (e.g., internet forums and through Facebook ${ }^{3}$ ). The analysis of content of local government papers was focused on defining functions that are performed by carriers of local government information during the election campaign.

\footnotetext{
2 Territorial division in Poland has three levels. The basic administrative unit is a commune (gmina). A group of neighboring communes is a poviat and several poviats comprise a voivodship. Each of these units is hierarchically independent and has different tasks. A commune takes up tasks that concern everyday life of its residents, a poviat cares for supra-local social infrastructure (e.g., social welfare institutions, hospitals) and supra-local roads. The voivodship, on the other hand, is responsible for regional development. Another category are communes that also carry out some tasks of poviats-the so-called cities with poviat rights. They differ from poviats in the form of authority. In poviats, the executive is the management board elected by the legislative body, similarly to a voivodship. On the other hand, in communes and cities with poviat rights, the executive power is held by mayors (called burmistrz or prezydent - depending on the size of the local government unit). Mayors of communes and cities with poviat rights are elected in general direct elections. The candidate who collects the largest number of votes wins.

3 Facebook is the most popular social medium in Poland, according to data of January 2015 http://www.wirtualnemedia.pl/artykul/19-2-mln-internautow-w-polsce-najpopularniejszymi-serwisami-google-yt-allegro-fb-onet-i -wp-w-dol-nk-pl- access on 22 January 2015.
} 
The research and publication of this paper were co-financed from the statutory activity funds of the Faculty of Management and Social Communication of the Andrzej Frycz Modrzewski Krakow University in Krakow, awarded in 2014.

\section{Analyzing the Content of Local Government Magazines}

The analysis of content of local government press during the local election campaign revealed publishing information concerning two main topics:

(1) Appealing to rationality of voters by presenting development of the city, promoting the implemented or prepared investments (mainly infrastructural, but not only). Also social or health projects dedicated directly to residents were subject of publication. As Radosław Markowski points out:

...the modern citizen in the world of politics - acts purposefully on the basis of the obtained beliefs, aspirations and ambitions, looking at the same time at what their nearest social environment does in this political matter. /.../ What is worth emphasizing, this citizen makes assessments and acts in accordance with them, relying on somewhat imperfect and limited information. (Markowski, 2010, pp. 21-22)

Research carried out in 2011 concerning sources of voters' support quite unequivocally revealed that support for current mayors is the effect of local development, exemplified by growing infrastructure and new investments shaping the standard of living of residents (Piechota, 2013). Local government press is also the main carrier of information directed at certain groups of voters and concerning the taken up activities addressed to these groups.

(2) Reinforcing and promoting the positive image of the mayor seeking reelection with the use of propaganda, mainly visual, i.e., photos that also increase their recognizability (at the same time in the papers there are no photos of competitors in the elections); native advertising and formulating emotional messages. The analysed magazine issues practically did not tackle topics that would be uncomfortable for the authorities, there were no controversial topics in them or topics that would stir emotions in the community. Magazines issued by municipal companies published interventions of residents - concerning only petty cases connected with the place of residence of the person taking up the intervention. It was noticeable that there was no pluralism of content and no access to media for other entities than those connected with the authority (legal solutions do not put local government media under the obligation of leaving some space for other entities existing at the local government level—political opposition, NGOs, self-regulatory organizations).

Among the studied municipal papers, also available in the electronic version, only 23 percent provided space for public debate on the social website Facebook, on the papers' own fanpage. On the other hand, no magazine had their own internet forums, making it possible to comment on the published content. Posts generated on fanpages of local government press do not contain topics that would engage residents in discussing the matters of the city. In particular on the fanpages' walls the editors do not generally publish texts that have been printed, what makes discussion over the content of articles impossible. Topics concerning matters that could make users discuss them are avoided as well as topics concerning problems of cities - the tackled topics are only the uncontroversial ones. Walls on magazines' Facebook fanpages are treated as information booklets used for publishing unimportant things ${ }^{4}$. As a result, the magazines' fanpages are not popular among readers - although the number of fans, depending on the city, is between almost two thousand

\footnotetext{
${ }^{4}$ Similar research conclusions were formulated after the analysis of content and course of communication processes during the election campaign in 2010. More in Piechota (2011).
} 
and nearly thirty thousand ${ }^{5}$, but their engagement is very small, both concerning "liking" posts, commenting on them and sharing them - some posts do not raise any reaction of users, others are sometimes "liked" and rarely commented on. The particularly noticeable comments present the same opinions as the ones shared by the town hall in the magazine. This confirms the results of research over tribalism carried out by Michael Maffesoli, who emphasized the importance of social websites as the return to communication of individuals in a tribal community, where people share the same point of view. Individuals with different opinions are removed from the community (Maffesoli, 2008, p. 11). On the other hand, Manuel Castells pointed out that the individual enters into relations, develops their competence in horizontal communication thus reinforcing the sense of their own identity by being the member of a given structure (Castells, 2009). Still, Abraham Moles mentioned the phenomenon of an "electronic galaxy"-a group that creates the network resembling tribal structures, whose features include interactivity and temporariness (Moles, 1986). However, Mike Westling saw Facebook as the virtual forum, a place where users have the right to present their opinions, share their views, and critically assess the reality, regardless of the place there are in (Piechota, 2012). The process of communication going on fanpages of local government magazines did not confirm interactivity and did not point to the importance of development of horizontal communication in the local community, either. It definitely does not create the virtual forum where opinions and different points of view clash.

Research has also revealed that in the majority of cases local government magazines are usually one of the entities providing information at a local level. Thus there are many sources of information for residents but with the assumption that local government papers are available free of charge. Patrycja Szostok, studying local government media in selected Polish cities, pointed to the phenomenon that a lower number of local media influences the lower level of political content of the message (Szostok, 2013). Commercial media that exercise a controlling function are often focused on messages verifying the activities of authorities, at the same time compelling local government media to formulate messages supporting the positive image of local authorities to keep balance in presenting information about the city to the public.

Propaganda is widely used both in choosing content that is disseminated and through visual messages - photographs. In local government magazines there are no texts that would show the policy carried out by authorities in an unfavorable light, that would challenge the activities of acting mayors or even the ones that would mention undertakings that were not successful or whose implementation was met with social protest. The papers mainly contain information about successes achieved by local authorities or achievements of individual residents. The latter element of content is usually accompanied by visual propaganda messages (photos of the mayor with people in the light of whom, in accordance with the halo effect, the positive image of the mayor is reinforced) (Cialdini, 2009).

Analyzing the content of local government magazines in the period of election campaign it is worth to note the use of native advertising, joining editorial content and marketing messages, in this case political advertising. By joining advertising content with messages concerning presentation of the carried out investments or achieved successes, the image of the mayor seeking reelection is subconsciously reinforced in the recipient's mind. Elements of native advertising can also be noticed in juxtaposing evocative titles of articles where candidates in the elections are presented through their different character features, e.g., a conciliative candidate who is willing to cooperate versus a confrontational candidate, whom colleagues do not

\footnotetext{
${ }^{5}$ The fanpage of a magazine that publishes information about culture and events taking place in the city has nearly thirty thousand fans.
} 
want to cooperate with. The analysis of the content of 73 local government magazines has shown that such practices were not a one-time occurrence, they could be found both in local government magazines issued directly by town halls and in magazines published by municipal companies.

In order to reinforce the image of mayors seeking reelection, in local government magazines there were messages with emotional character, emphasizing the human, affectionate dimension of the candidate, their personal, and spontaneous engagement in the matters of the residents. Articles containing such messages often took the form of reports from events the mayor took an active part in, helping residents or appreciating successes achieved by them. Arlie Russel Hochschild emphasizes that

...emotions convey certain information for us. They perform, like Freud's fear, the "signaling function". Thanks to feelings we get to know our own point of view about the world. /.../ the phenomena, that we treat as the ones inherently connected with feelings or emotions have always taken the social form suitable at a given moment and were used in the social life. (Hochschild, 2009, pp. 19-20)

As Hochschild points out, currently we more and more strongly emphasize the process connected with "not managing emotions", treating the natural and the spontaneous as the most valuable. This results from the culturally imposed need to shape an internal instrumental attitude towards feelings. The feeling is treated spontaneously, put on the pedestal like a virtue, something rare and valuable. Emotions are now the most powerful tool used for managing the actions of people (Hochschild, 2009, pp. 24, 61). Using emotions in messages describing the mayor's engagement in the matters of the local community is important for shaping attitudes and opinions of residents, what may be treated as the element of political culture, supporting certain values in the local community (Halman, 2010). Being guided by the widespread demand for values in politics (Halman defines them as new political values), local government press has emphasized not only the features of the governing leader that were directed at supporting the development and reinforcing ties in the local social capital but also identified emotions that the mayor (seeking reelection) evoked in the local community.

\section{Summary}

Local government magazines play an important role in Poland - they fill information gaps, providing content important for the local community that does not find its place in other local media. They also participate in promoting local social, cultural or civic initiatives. Many of them have an important share in promoting local activity, passing on information influencing the support of the local civic society. However, it cannot be neglected that it is not the evidence of democratization of the message addressed to the local community that only information that does not make the authorities reflect on the implementation of local policy is passed on and that the voice of other local organized social groups is omitted in magazines financed from public money. Some editors of magazines consciously build messages, at the same time limiting the possibility of discussion over their content—not creating the platform for discourse or limiting the scope of allowed dialogue to topics that are not very important from the perspective of the local community. Another issue is the fact that the still weak forms of social control in Poland and the low level of citizens' engagement in public matters are acknowledged in the lack of objection of local communities or leaders of different organizations, including NGOs, against the content published in magazines that are financed from public money. Development of network communication sets a new area of power creation. Describing mechanisms of including an individual into individualized mass communication, Castells simultaneously emphasizes the process of creating power on the internet. Medium is not the message, as Castells writes, but it conditions the 
form and way of propagating the message (information in an attractive printed and electronic form is available free of charge). Local government press does not only construct meanings but it also creates a certain cultural context for them, through propaganda or emotional messages showing the direction of interpreting meanings. Introducing access control for users, by excluding or limiting the possibility of commenting on information, accompanied by the low level of civic and communicational competences among Poles, in fact shuts off discourse, replacing it with networked power (Castells, 2013, p. 411). In accordance with the definition proposed by Castells, it is the type of power that consists in the possibility of setting the hierarchy of topics, managing and taking editorial decisions. He writes:

Political power of creating networks that provides the possibility of defining rules and courses of action in the area of politics depends on the victory in the fight for access to political offices and obtaining support (or at least lack of opposition) from citizens. /.../ the fundamental mechanism of obtaining access to political power and possibility to take decisions is media policy. (Castells, 2013, p. 415)

To sum up the above considerations, press issued by local government bodies, additionally made available in the electronic version, plays an important role, not only informative. During the election campaign the local government press is first of all the information carrier that supports the local leader directly (reinforcing and promoting their image) or indirectly (by presenting the implemented tasks and investments and thus appealing to the rational attitudes of voters). So far, the relationship between the fact of issuing their own media with content shaped by local government authorities and the ability to be reelected has not been directly pointed to in Poland. The research carried out in 2011 (Piechota, 2013) revealed that mayors who communicate with the local community through their own media tend to be reelected more often, but the power and the ability to hold it have a multi-dimensional character. It is thus impossible to formulate conclusions making it possible to unambiguously point to the importance of the local government media (issued in the form of press or through other carriers) in local election campaigns. However, it can be assumed that due to their availability they are the source of information for many members of local communities.

\section{References}

Castells, M. (2009). The power of identity. Warszawa: Wydawnictwo Naukowe.

Castells, M. (2013). Communication power (p. 411). Warszawa: Wydawnictwo Naukowe PWN.

Chorązi, W., \& Dziki, S. (2004). Prasa lokalna i regionalna (Local and regional press). In Z. Bauer, \& E. Chudziński (Eds.), Dziennikarstwo i świat mediów (p. 121). Kraków.

Cialdini, R. (2009). Influence, science and practice. Gdańsk: Gdańskie Wydawnictwo Psychologiczne.

Halman, L. (2010). Wartości polityczne (Political values). In R. J. Dalton, \& H. D. Klingemann (Eds.), Zachowania polityczne t.1 (p. 359). Warszawa: Wydawnictwo Naukowe PWN.

Hochschild, A. R. (2009). The managed heart: The commercialization of human feeling. Warszawa: Wydawnictwo Naukowe PWN.

Kowalczyk, R. (2003). Prasa lokalna w systemie komunikowania spotecznego (Local press in the system of social communication). Instytut Nauk Politycznych i Dziennikarstwa Uniwersytetu im, Adama Mickiewicza, Poznań.

Maffesoli, M. (2008). The time of the tribes. Warszawa: Wydawnictwo Naukowe PWN.

Markowski, R. (2010). Przedmowa do wydania polskiego (Preface to the Polish edition). In R. J. Dalton, \& H. K. Klingemann (Eds.), Zachowania Polityczne t.1 (pp. 21-22). Warszawa: Wydawnictwo Naukowe PWN.

Moles, A. (1986). Theorie structurale de la communication et societes. Paris

Piechota, G. (2011). Application of social media in political communication of local leaders in election processes (on the example of Facebook's use by mayors of voivodship cities in Poland in the 2010 election campaign). Central European Political Studies, No. 4. 
Piechota, G. (2012). Zarządzanie procesem komunikowania w mediach społecznościowych przez miasta Metropolii Silesia i ich prezydentów (Managing the process of communication in social media by cities of the Silesian Metropolis and their mayors). Zarzqdzanie Publiczne, 4(22), 52-68.

Piechota, G. (2013). Źródła poparcia wyborczego lokalnych liderów w samorządowych kampaniach wyborczych (na przykładzie kampanii wyborczych prezydentów miast na prawach powiatu w 2010 roku) [Sources of voters' support for local leaders in local government election campaigns (on the basis of election campaigns for mayors of cities with poviat rights in 2010]. Środkowoeuropejskie Studia Polityczne, No. 2.

Sobczak, J. (2005). Wolność pracy w myśl litery prawa i w praktyce prasy lokalnej (Freedom of work in law and practice of local press). In J. Chłopecki, \& R. Polak (Eds.), Media lokalne a demokracja lokalna (p. 62). Wydawnictwo Wyższej Szkoły Zarządzania i Informatyki w Rzeszowie, Rzeszów.

Szostok, P. (2013). Prasa samorzqdowa, czy prasa wladz samorzqdowych Komu stuża periodyki finansowane z lokalnych budżetów (Local press or local government press: Who do the magazines financed from local budgets serve]. Wydawnictwo Gnome, Katowice.

Szostok, P., \& Rajczyk, R. (2013). Komunikowanie lokalne w Polsce: O instrumentach polityki komunikacyjnej samorzqdów (Local communication in Poland: On the instruments of local governments' communication policy). Wydawnictwo Gnome, Katowice. 